\title{
Vibrational spectral studies of solutions at elevated temperatures and pressures. X.Raman spectral study of aqueous cadmium bromide solutions at 25 and 200 DegC
}

Citation for published version (APA):

Anderson, B. G., \& Irish, D. E. (1988). Vibrational spectral studies of solutions at elevated temperatures and pressures. X.Raman spectral study of aqueous cadmium bromide solutions at 25 and 200 DegC. Journal of Solution Chemistry, 17(8), 763-775. https://doi.org/10.1007/BF00647421

DOI:

10.1007/BF00647421

Document status and date:

Published: 01/01/1988

Document Version:

Publisher's PDF, also known as Version of Record (includes final page, issue and volume numbers)

Please check the document version of this publication:

- A submitted manuscript is the version of the article upon submission and before peer-review. There can be important differences between the submitted version and the official published version of record. People interested in the research are advised to contact the author for the final version of the publication, or visit the DOI to the publisher's website.

- The final author version and the galley proof are versions of the publication after peer review.

- The final published version features the final layout of the paper including the volume, issue and page numbers.

Link to publication

\footnotetext{
General rights

- You may freely distribute the URL identifying the publication in the public portal. follow below link for the End User Agreement:

www.tue.nl/taverne

\section{Take down policy}

If you believe that this document breaches copyright please contact us at:

openaccess@tue.nl

providing details and we will investigate your claim.
}

Copyright and moral rights for the publications made accessible in the public portal are retained by the authors and/or other copyright owners and it is a condition of accessing publications that users recognise and abide by the legal requirements associated with these rights.

- Users may download and print one copy of any publication from the public portal for the purpose of private study or research.

- You may not further distribute the material or use it for any profit-making activity or commercial gain

If the publication is distributed under the terms of Article $25 \mathrm{fa}$ of the Dutch Copyright Act, indicated by the "Taverne" license above, please 


\title{
Vibrational Spectral Studies of Solutions at Elevated Temperatures and Pressures. $X$. Raman Spectral Study of Aqueous Cadmium Bromide Solutions at 25 and $200^{\circ} \mathrm{C}$
}

\author{
Bruce G. Anderson ${ }^{1}$ and D. E. Irish ${ }^{1,2}$ \\ Received December 4, 1987; Revised April 14, 1988
}

\begin{abstract}
The Raman spectra of cadmium bromide solutions with bromide to cadmium mole ratios varying from 1.0 to 9.74 were studied at $200^{\circ} \mathrm{C}$. Factor analysis revealed that three complexes contributed to the spectra. From a comparison with previous results at $25^{\circ} \mathrm{C}$ these species were identified as $\mathrm{CdBr}_{2}, \mathrm{CdBr}_{3}$, and $\mathrm{CdBr}_{4}^{2-}$ cadmium existed as the tetrabromo complex, $\mathrm{CdBr}_{4}^{2}$, at mole ratios greater than 5.99. A formation constant of $7 \pm 2$ was determined for $\mathrm{CdBr}_{4}^{2-}$ at $200^{\circ} \mathrm{C}$. No evidence of $\mathrm{Cd}\left(\mathrm{H}_{2} \mathrm{O}\right)_{6}^{2+}$ or $\mathrm{CdBr}^{+}$ was found, although electroneutrality dictates that one or both of these species must exist at low mole ratios.
\end{abstract}

KEY WORDS: Cadmium bromide complexing; Raman spectroscopy; temperature dependence of equilibria; aqueous high temperature electrolyte solutions.

\section{INTRODUCTION}

The rationale for this research has been presented in the preceding article. $^{(1)}$ Briefly stated, the objective has been to compare the interaction of $\mathrm{Zn}$ (II), (a "hard" cation), and $\mathrm{Cd}(\mathrm{II})$, (a "soft" cation) with the same "soft" anion, bromide, ${ }^{(2,3)}$ over a wide temperature range $\left(25^{\circ} \mathrm{C}\right.$ to $200^{\circ} \mathrm{C}$ ), as revealed by Raman spectroscopy. The coordination of both bromide and water to the cations, the change in geometry from octahedral for the fully aquated species to tetrahedral for $\mathrm{CdBr}_{4}^{2-}$, and the change in bromide ligand number with increased temperature are of interest.

\footnotetext{
${ }^{1}$ Guelph-Waterloo Centre for Graduate Work in Chemistry, Waterloo Campus, Department of Chemistry, University of Waterloo, Waterloo Ontario, N2L 3G1, Canada.

${ }^{2}$ To whom correspondence should be addressed.
} 
Cadmium exists in aqueous solution as a six-coordinate, octahedral ion, $\mathrm{Cd}\left(\mathrm{H}_{2} \mathrm{O}\right)_{6}^{2+} \cdot{ }^{(4)}$ In the presence of $\mathrm{Br}^{-}$, a series of ligand substitution reactions occurs and the corresponding bromo-cadmium complexes form. Evidence exists for the formation of mono-, di-, tri-, and tetrabromo complexes. ${ }^{(5)}$ Although this system has been extensively studied at $25^{\circ} \mathrm{C}$ by several different methods, large discrepencies in measurements of the relative stabilities of the species exist. ${ }^{(6)}$ An interpretation of ${ }^{113} \mathrm{Cd}$ chemical shifts relied heavily on the published equilibrim constants. ${ }^{(7)}$ Solutions of $0.1 M \mathrm{Cd}(\mathrm{II})$ at constant actual ionic strength 4.5 were studied; the dependence of the chemical shift on added $\mathrm{NaBr}$ was interpreted in terms of the four bromocadmium complexes specified above.

Several Raman studies have been conducted on this system at $25^{\circ} \mathrm{C}$. ${ }^{(8)}$ Prior to 1967 , Raman spectroscopy suggested that the only important ion is the tetrahedral $\mathrm{CdBr}_{4}^{2-}$, which gave rise to a polarized band at $166 \mathrm{~cm}^{-1}\left[\mathrm{~V}_{1}\left(a_{1}\right)\right]$ and a broad, depolarized band at circa $56 \mathrm{~cm}^{-1}$ $\left[v_{2}(e), v_{4}\left(f_{2}\right)\right.$ unresolved]. Evidence for the existence of lower complexes at low $\mathrm{Br}^{-}$concentrations was inconclusive. Davies and Long ${ }^{(9)}$ reported similar results for aqueous solutions but observed different bands with the solvent tri-n-butylphosphate. These bands were attributed to $\mathrm{CdBr}_{4}^{2-}\left[\mathrm{v}_{1}\left(a_{1}\right) 159 \mathrm{~cm}^{-1}, v_{3}\left(f_{2}\right) 188 \mathrm{~cm}^{-1}, v_{4}\left(f_{2}\right) 63 \mathrm{~cm}^{-1}\right]$, $\mathrm{CdBr}_{3}^{-}\left[\mathrm{v}_{1}\left(a_{1}^{\prime}\right) 168 \mathrm{~cm}^{-1}, v_{3}\left(e^{\prime}\right) 184 \mathrm{~cm}^{-1}, v_{4}\left(e^{\prime}\right) 58 \mathrm{~cm}^{-1}\right]$ and to $\mathrm{CdBr}_{2}$ $\left[v_{1}\left(\Sigma_{\mathrm{g}}^{+}\right) 186 \mathrm{~cm}^{-1}\right]$. In 1970 Macklin and Plane ${ }^{(10)}$ reported observation of all four complexes in aqueous solutions at temperatures up to $95^{\circ} \mathrm{C}$. The spectra did not contain isolated peaks, as observed for aqueous solutions of zinc bromide, but rather consisted of broad, overlapping bands. Many discrepancies exist in the Raman data cited here. These include differences in peak assignments and point group symmetries of the various species, and undoubtedly arise from severe band overlap. Study of this system at a higher temperature might therefore have the added advantage of resolving existing differences of interpretation at room temperature.

\section{EXPERIMENTAL}

A series of twelve cadmium bromide solutions was prepared gravimetrically; compositions were selected according to the mole ratio method. The concentration of $\mathrm{Cd}^{2+}$ was fixed at $1.0 \mathrm{~m}$ (i.e., mol- $\mathrm{kg}^{-1}$ water) and the mole ratio $R$, defined as the ratio of the moles of bromide ion to cadmium ion, was varied from 1.0 to 10 .

A stock solution of aqueous trifluoromethanesulfonic acid (TFMS) (Aldrich) was prepared by dilution of anhydrous TFMS in an 
Table I. Solution Compositions ${ }^{a}$

\begin{tabular}{ccccc}
\hline$R$ value & {$\left[\mathrm{Cd}^{2+}\right]$} & {$\left[\mathrm{Na}^{+}\right]$} & {$\left[\mathrm{Br}^{-}\right]$} & {$\left[\mathrm{SO}_{4}^{2-}\right]$} \\
\hline & 0.000 & 4.123 & 4.123 & 0.000 \\
1.01 & 1.196 & 1.208 & 1.208 & 1.196 \\
1.49 & 0.985 & 1.468 & 1.468 & 0.985 \\
2.00 & 0.967 & 0.000 & 1.934 & 0.000 \\
2.52 & 1.324 & 0.682 & 3.330 & 0.000 \\
2.96 & 1.118 & 1.073 & 3.039 & 0.000 \\
3.49 & 1.137 & 1.696 & 3.970 & 0.000 \\
3.96 & 0.976 & 1.915 & 3.867 & 0.000 \\
5.99 & 0.978 & 3.899 & 5.855 & 0.000 \\
7.47 & 0.930 & 5.091 & 6.951 & 0.000 \\
9.24 & 0.999 & 7.228 & 9.226 & 0.000 \\
9.74 & 0.940 & 7.269 & 9.152 & 0.000 \\
\hline
\end{tabular}

${ }^{a}$ Concentrations are expressed as total available species in all forms $\mathrm{mol}-\mathrm{kg}^{-1}\left(\mathrm{H}_{2} \mathrm{O}\right)$ $\left[\mathrm{CF}_{3} \mathrm{SO}_{3} \mathrm{H}\right]=1.002 \mathrm{~m}$

appropriate amount of Millipore ${ }^{\mathrm{TM}}$ deionized water within a nitrogenfilled glovebag. The solution was then standardized by titration with aqueous sodium hydroxide solution. This stock solution was used as the solvent for all solutions; the TFMS prevented hydrolsis of $\mathrm{Cd}^{2+}(\mathrm{aq})$ and provided an internal standard for quantitative intensity measurements in the Raman spectra.

$\mathrm{CdBr}_{2} \cdot 4 \mathrm{H}_{2} \mathrm{O}$ (Fisher certified) was used as a source of $\mathrm{Cd}^{2+}$ and $\mathrm{Br}^{-}$for solutions with $R$ values $>2$. The solute was used as received. Solutions with $R$ greater than 2 also contained $\mathrm{NaBr}$ (BDH, 99.9\%) which was dried at $110^{\circ} \mathrm{C}$ for two hours prior to use. $8 \mathrm{CdSO}_{4} \cdot 3 \mathrm{H}_{2} \mathrm{O}$ (BDH, 99\%) and $\mathrm{NaBr}$ were used to prepare solutions with mole ratios less than 2.0. A blank solution was prepared with $\mathrm{NaBr}(4.123 \mathrm{~m})$ in TFMS. A summary of the solution compositions is given in Table I. Concentrations are total available species in all forms in moles per $\mathrm{kg}$ $\mathrm{H}_{2} \mathrm{O}$.

Samples were heated in a furnace assembly previously described. ${ }^{(11)}$ Boiling of the sample at elevated temperatures was prevented by application of hydrostatic pressure (typically $7 \mathrm{MPa}$ ). No vapor phase was present. The temperature was monitored by a Type $\mathrm{K}$ chromel-alumel thermocouple and was stable within $\pm 0.5^{\circ} \mathrm{C}$ at $200^{\circ} \mathrm{C}$. The furnace allowed collection of the scattered radiation at 90 degrees to the incident beam. 
Raman spectra were recorded using a Jarrell-Ash 25-100 1.0 metre double Czerny-Turner monochromator, with a 129 digital cosecant stepping drive, an RCA 31034 selected photomultiplier, and an SSR $1105 / 1120$ photon counting system. A Coherent INNOVA model 70 argon ion laser operating at $488.0 \mathrm{~nm}$ at a power of $600 \mathrm{~mW}$ provided the excitation source for all spectra. A Commodore PET model 2001 microcomputer controlled all experiments. Spectra were stored on a floppy disk (Commodore Model 2040) and were plotted using an HP Model 74 plotter.

The Raman spectra of the cadmium bromide solutions were recorded at $25^{\circ} \mathrm{C}$ and $200^{\circ} \mathrm{C}$ at $7 \mathrm{MPa}$ pressure in the region $25 \mathrm{~cm}^{-1}$ to $250 \mathrm{~cm}^{-1}$. All spectra were recorded at $0.5 \mathrm{~cm}^{-1}$ intervals with a 5 second time constant and a spectral slit width of $5.8 \mathrm{~cm}^{-1}$. The absolute wavenumber position was calibrated for each run using the $515.196 \mathrm{~nm}$ line of a neon discharge lamp. Stated wavenumber positions are accurate to within $\pm 1 \mathrm{~cm}^{-1}$. The region from $1000 \mathrm{~cm}^{-1}$ to $1075 \mathrm{~cm}^{-1}$ was recorded for quantitative analysis of band intensities and the $1032 \mathrm{~cm}^{-1}$ $\left(\mathrm{V}_{1} \mathrm{SO}_{2}\right)$ band of the anion of TFMS was used as an internal intensity standard.

\section{RESULTS AND DISCUSSION}

The Raman spectrum of cadmium bromide in trifluoromethanesulfonic acid, $R=9.74$, is shown in Fig. 1 . The region 25 to $250 \mathrm{~cm}^{-1}$ is dominated by a symmetric, polarized peak at $159 \mathrm{~cm}^{-1}$, full width at half maximum, FWHM $=18 \mathrm{~cm}^{-1}$. In addition a very broad, depolarized band occurs at circa $55 \mathrm{~cm}^{-1}$. The bands have been reported previously; the former was assigned to $v_{1}\left(a_{1}\right)$ and the latter to $v_{2}(e)$ and $v_{4}\left(f_{2}\right)$ (unresolved) of the tetrahedral $\mathrm{CdBr}_{4}^{2-}$ complex.

Previous studies have shown that exponential quadratic functions of the form

$$
Y=A_{1} \exp \left[P_{1} X\right]+A_{2}+A_{3}\left(P_{2}-X\right)+A_{4}\left(P_{2}-X\right)^{2}
$$

yield suitable empirical baselines in this region close to the Rayleigh line. ${ }^{(12)}$ Attempts were made to correct the spectra with this function via nonlinear least squares regression. Although adequate for spectra of solutions with low $R$ values, the presence of the low frequency bending modes at higher $R$ values hampered selection of suitable values of baseline coordinates required by the program. It was found that the empirical baseline was dependent upon the initial choice of these data points near $25 \mathrm{~cm}^{-1}$. The broad, low-energy band undoubtedly extends into this region. 


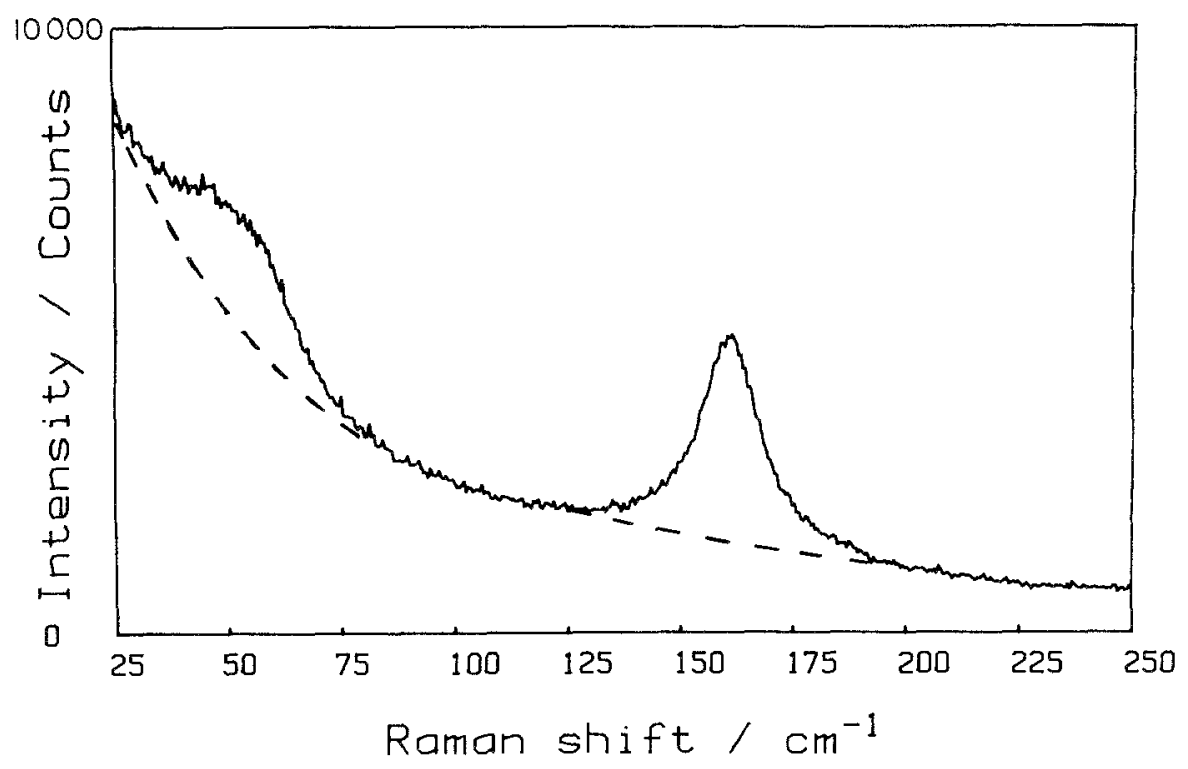

Fig. 1. Raman spectrum of cadmium bromide in TFMS(aq), $R=9.74,25^{\circ} \mathrm{C}$.

Attempts were made to correct the spectra by subtracting the spectrum of a sodium bromide solution. Although adequate at room temperature and at low $R$ values, at $200^{\circ} \mathrm{C}$ the blank spectrum showed a consistently smaller curvature of the Rayleigh wing than the spectra of the samples. The concentrated $\mathrm{CdBr}_{2}-\mathrm{NaBr}$ solutions apparently have an altered solvent structure and hence Rayleigh scattering.

A linear extrapolation between 125 and $200 \mathrm{~cm}^{-1}$ produced consistent and reproducible baselines. Fig. 2 shows a comparison between the exponential quadratic function and the linear extrapolation with the inset showing the resulting corrected spectra. The total integrated areas differ by less than $5 \%$.

Effects caused by the temperature dependence of the complexation equilibria were most readily observed in the spectra of solutions with low $R$ values. Fig. 3 shows the spectra of the stoichiometric $\mathrm{CdBr}_{2}$ solution at $25^{\circ} \mathrm{C}$ and at $200^{\circ} \mathrm{C}$. The peak maximum at $159 \mathrm{~cm}^{-1}$ shifts to higher frequencies with increasing temperature. Considerable broadening of the band and high-frequency asymmetry are also observed.

Fig. 4 shows the dependence of the band envelope upon mole ratio at a constant temperature of $200^{\circ} \mathrm{C}$. As the mole ratio increases, the band envelope loses its high frequency asymmetry. This loss causes the envelope to narrow and shift to low frequencies. For solutions 


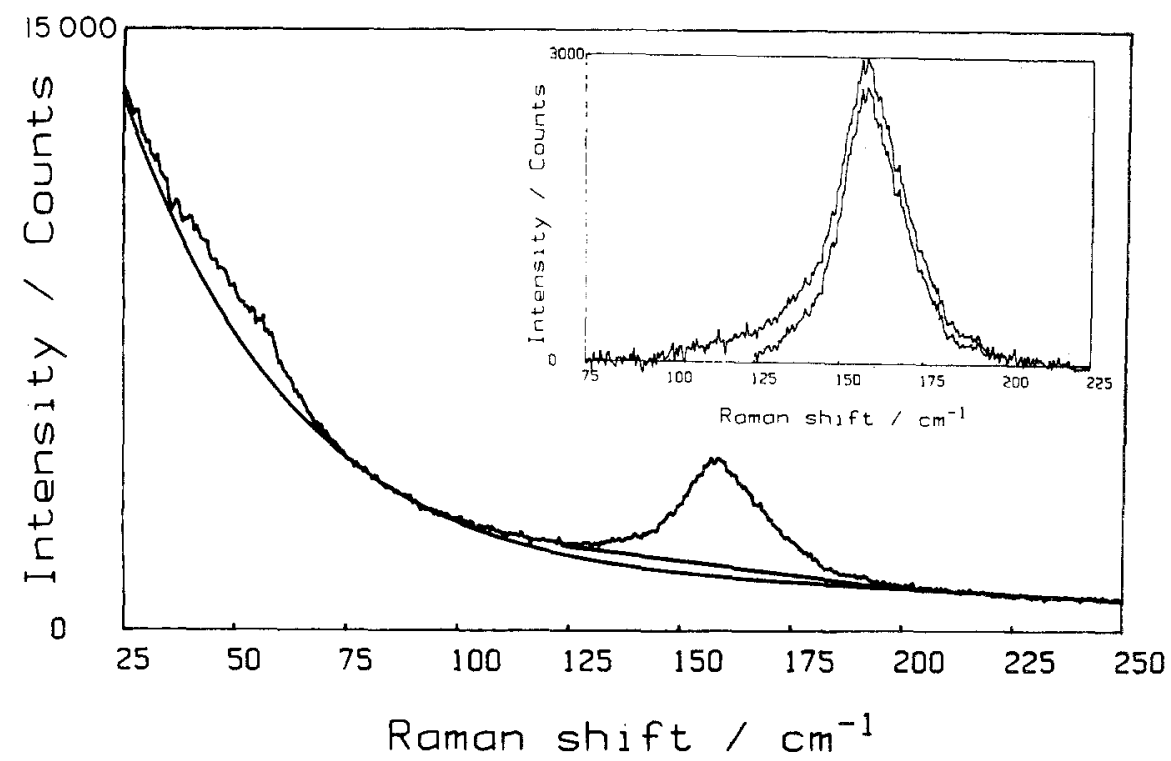

Fig. 2. A comparison between the exponential quadratic and the linear baseline correction methods.

having $R>5.99$, a symmetric peak (FWHM $=18 \mathrm{~cm}^{-1}$ ) at $159 \mathrm{~cm}^{-1}$ was observed.

As previously discussed, the Raman spectra of solutions containing cadmium bromide complexes are dominated by broad featureless bands. No shoulders or new bands appear with either changing mole ratio or changing temperature. Only subtle changes in band position and asymmetry are observed which makes quantitative information difficult to extract and conclusions related to symmetries of the complexes nearly impossible to achieve. Fig. 5 shows the dependence of the total integrated intensity of the $159 \mathrm{~cm}^{-1}$ band (relative to $1.0 \mathrm{~m}$ TFMS anion) upon mole ratio. The curves attain a plateau at both $25^{\circ} \mathrm{C}$ and $200^{\circ} \mathrm{C}$, where the relative intensity is independent of mole ratio. At high bromide concentrations, all of the cadmium present has apparently been complexed as a single species. This result, coupled with the constant band position and FWHM, suggests that at high $R$ values only the tetrabromocadmate complex exists. The shapes of these curves are similar to that showing the dependence of the ${ }^{113} \mathrm{Cd}$ chemical shift on $\mathrm{NaBr}$ concentration, ${ }^{(7)}$ although the concentrations used in the present study were necessarily higher.

The asymmetry observed at low $R$ values suggests that several species coexist in solution. In order to obtain information on the 


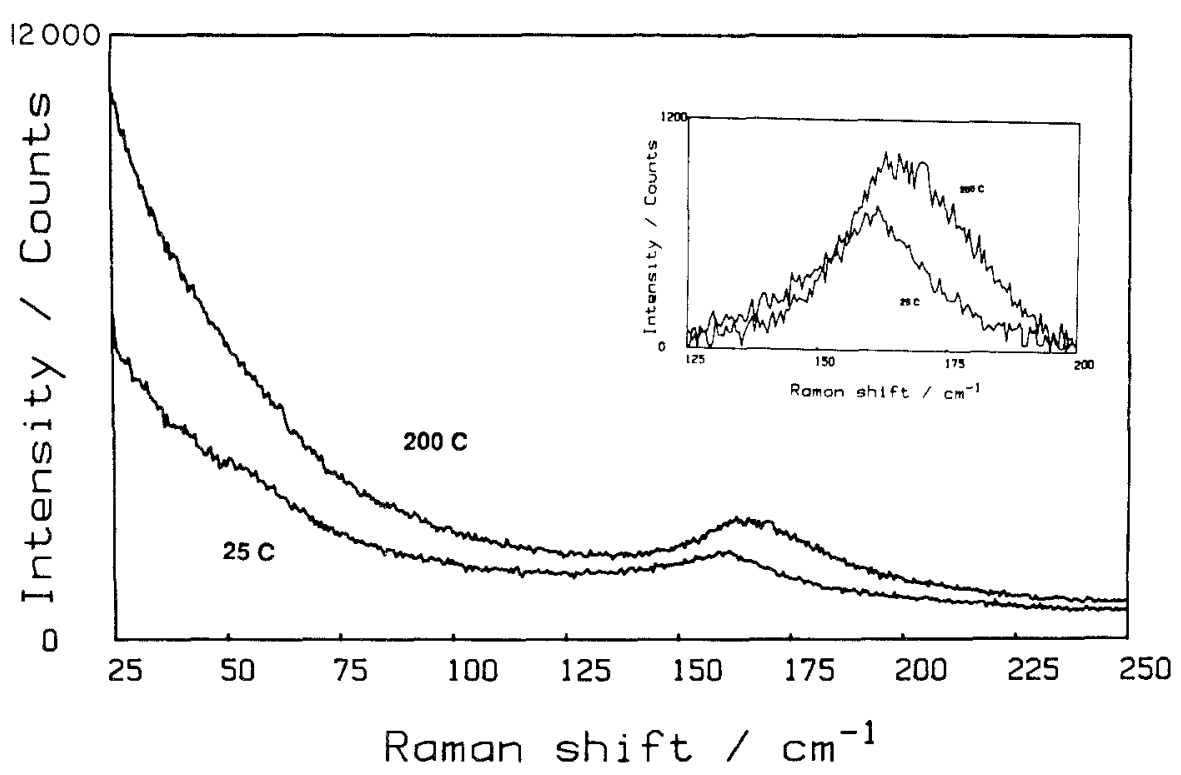

Fig. 3. The temperature dependence of the Raman specta of the $1.0 \mathrm{~m} \mathrm{CdBr}_{2}$ solution.

number of species present at $200^{\circ} \mathrm{C}$ the matrix method of factor analysis was employed. This technique is discussed in detail in a book by Malinowski and Howery. ${ }^{(\mathbf{1 3})}$ Factor analysis has now been employed successfully in a number of Raman spectral studies. ${ }^{(14,15)}$ Eleven spectra obtained from $125-200 \mathrm{~cm}^{-1}$, for solutions with $R$ values between 1.00 and 9.74 were analyzed using the Target factor analysis computer programs of Malinowski. ${ }^{(16)}$ This treatment revealed that three species contribute to the spectra at $200^{\circ} \mathrm{C}$ over this range of mole ratios. Attempts to isolate the spectra of these three components using the spectral isolation method ${ }^{(17)}$ failed. This method demands that the spectrum of each component must have at least one point, unique from the others. This requirement is not met here, because of the severe band overlap.

As discussed in the introduction, the symmetric stretching frequencies of the di-, tri, and tetrabromocadmium complexes have been reported at $25^{\circ} \mathrm{C}$. At $200^{\circ} \mathrm{C}$ the band envelopes obtained from solutions having low $R$ values were consistent with the presence of these three species. The relative intensity of each component was determined by deconvoluting each spectrum using the program BNDFT. ${ }^{(18)}$ This analysis was made by adopting the following constraints:

1. Because no shift in $v_{1}$ of $\mathrm{CdBr}_{4}^{2-}$ was observed with in- 


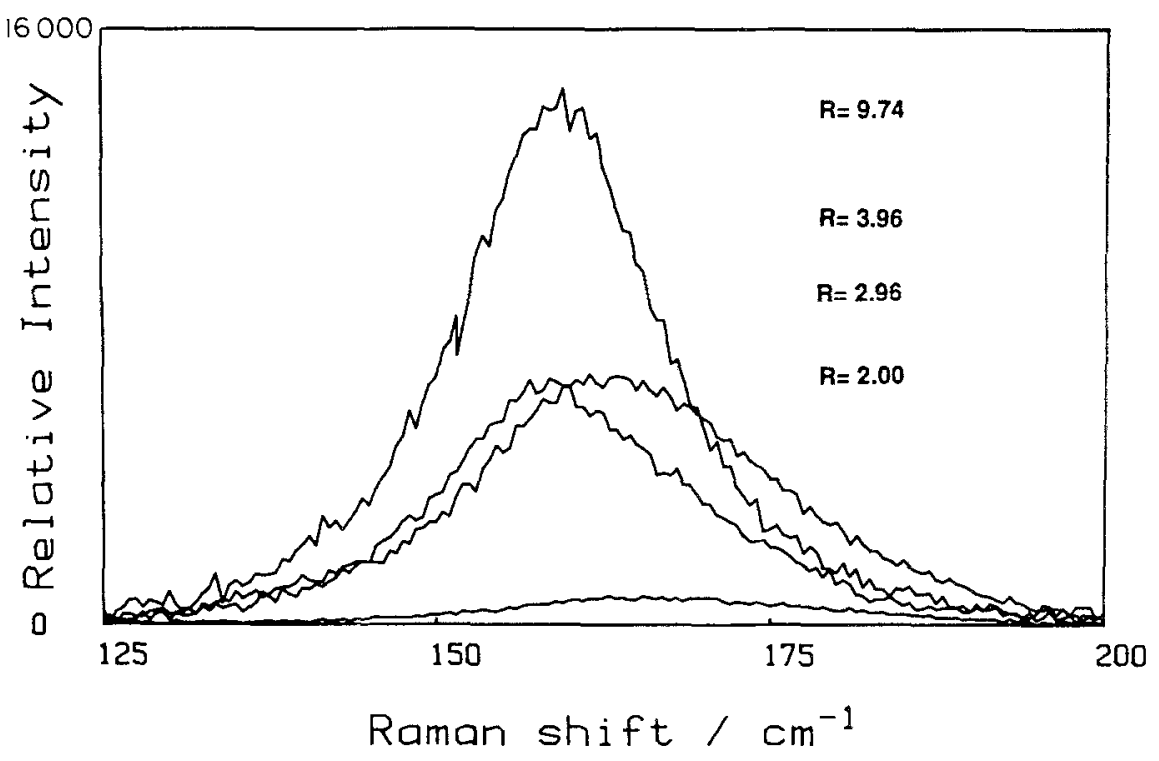

Fig. 4. Band envelope dependence upon mole ratio at $200^{\circ} \mathrm{C} ; 1.0 \mathrm{~m} \mathrm{CdBr}_{2}+\mathrm{NaBr}$.

creasing temperature, the modes of the dibromo and tribromo species were assumed to be similarly unaffected.

2. The symmetric peaks of solutions having $R$ values of 5.99 or greater yielded a single band at $159 \mathrm{~cm}^{-1}$ (FWHM $=18$ $\mathrm{cm}^{-1}$ ) and this value was adopted for $\mathrm{CdBr}_{4}^{2-}$.

3. All other spectra were initially constructed with three bands whose positions were fixed according to previous observations. ${ }^{(9)}$ The FWHM of the $159 \mathrm{~cm}^{-1}$ band was fixed at $18 \mathrm{~cm}^{-1}$, as observed in the spectra at high $R$ values.

Fitted band envelopes revealed that only two bands, 159 and 168 $\mathrm{cm}^{-1}$, were required in the region $3.49<R<5.99$. For lower $R$ values all three were needed. Fig. 6 shows a typical deconvoluted spectrum with its three components at 159,168 and $183 \mathrm{~cm}^{-1}$. The results of deconvolution are shown as the percentage of the total integrated intensity due to each component (Fig. 7). Several trends are obvious:

1. The tribromocadmate complex dominates at low mole 


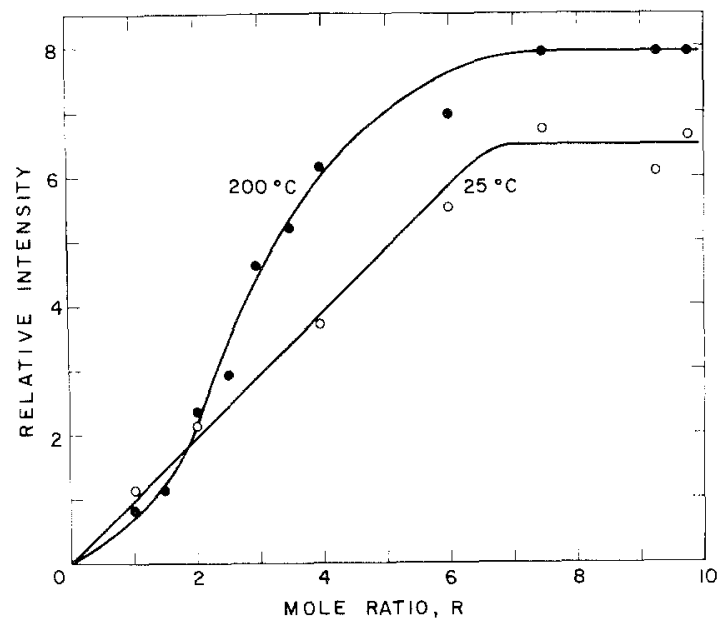

Fig. 5. Total relative integrated intensity of the $160 \mathrm{~cm}^{-1}$ band envelope $v s$. mole ratio, at 25 and $200^{\circ} \mathrm{C}$ for $\left[\mathrm{Cd}^{2+}\right]=1.0 \mathrm{~m}$.

ratios, diminishing steadily until vanishing at about $R=6$;

2. The intensity due to $\mathrm{CdBr}_{4}^{2-}$ increases steadily with increasing mole ratio until it alone exists at and above $R=6$;

3. The dibromo species makes only a minor contribution at low $R$ values and drops off sharply. Reproducible data could not be obtained for mole ratios less than 1.49 because of low signal-to-noise ratios.

Because all cadmium exists as the tetrabromo complex at high mole ratios, the molal scattering coefficient, $J_{4}^{200}$, could be calculated for this species at $200^{\circ} \mathrm{C}$. An average value of $7.9 \pm 0.1$ was obtained over three solutions relative to $1.0 \mathrm{~m}$ TFMS anion. Similar calculations at $25^{\circ} \mathrm{C}$ gave $J_{4}^{25}=6.5 \pm 0.3$. Thus the ratio of the molar intensities of the species $\mathrm{CdBr}_{4}^{2-}, J_{4}^{200} / J_{4}^{25}$, is 1.22 . This ratio must be corrected by the Bose-Einstein thermal population factor before comparisons can be made. Each value of $J$ is a ratio of two intensities viz. that of $\mathrm{CdBr}_{4}^{2-}$ at $159 \mathrm{~cm}^{-1}$ and that of the reference anion at $1032 \mathrm{~cm}^{-1}$. The factor of interest is ${ }^{(19)}$

$$
B_{v}^{\mathrm{T}}=[1-\exp (-h c v / k T)]
$$

Therefore the correction factor to the ratio $J_{4}^{200} / J_{4}^{25}$ is: 


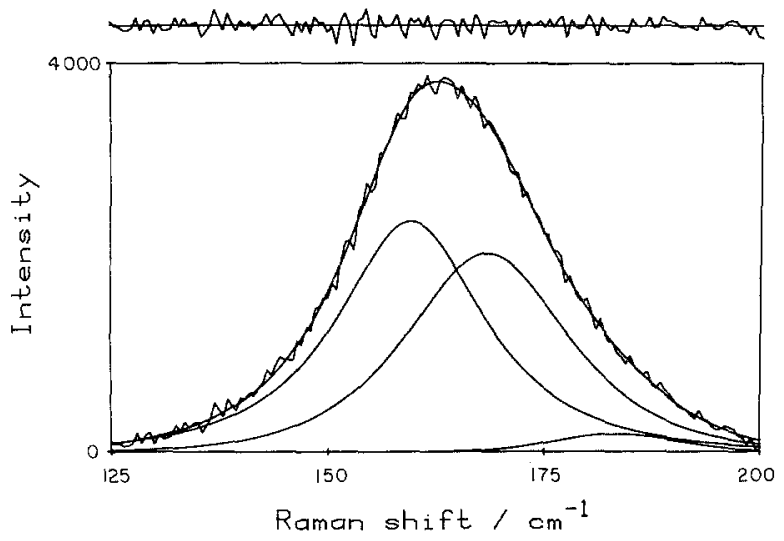

Fig. 6. A typical deconvoluted spectrum with its three components. $R=2.96,200^{\circ} \mathrm{C}$.

$$
\left(B_{159}^{200} / B_{1032}^{200}\right)\left(B_{1032}^{25} / B_{159}^{25}\right)=0.743
$$

and the corrected ratio $J_{4}^{200} / J_{4}^{25}$ is 0.906 . Thus the observed intensity increase is actually less than that expected from the temperature increase. Other factors such as the lowered dielectric constant of the medium and the lower density may also contribute to the intensity change. The correction is not required in the following calculations of species concentrations because data for each temperature are treated independently.

For intermediate mole ratios $(3.49<R<3.92)$ only the tribromo and tetrabromo complexes exist. Thus the total intensity is given by

$$
I=I_{4}+I_{3}=J_{4} C_{4}+J_{3} C_{3}
$$

Because $I_{4}$ and $J_{4}$ are known, the concentration of $\mathrm{CdBr}_{4}^{2-}$ can be determined. The concentration of $\mathrm{CdBr}_{3}^{-}$was then calculated, since all available cadmium exists in one or other of these two forms (square brackets indicate concentrations on the molality scale).

$$
\left[\mathrm{CdBr}_{3}^{-}\right]=[\mathrm{Cd}]_{\text {total }}-\left[\mathrm{CdBr}_{4}^{2-}\right]
$$

The molal scattering coefficient of $\mathrm{CdBr}_{3}^{-}, J_{3}^{200}$, was then determined according to

$$
J_{3}^{200}=I_{3} /\left[\mathrm{CdBr}_{3}\right]
$$

An average value of $3.8 \pm 0.4$ was obtained. The equilibrium constant for the formation of $\mathrm{CdBr}_{4}^{2-}$ is given by

$$
K_{4}^{200}=\left[\mathrm{CdBr}_{4}^{2-}\right] /\left[\mathrm{CdBr}_{3}^{-}\right]\left[\mathrm{Br}^{-}\right]
$$




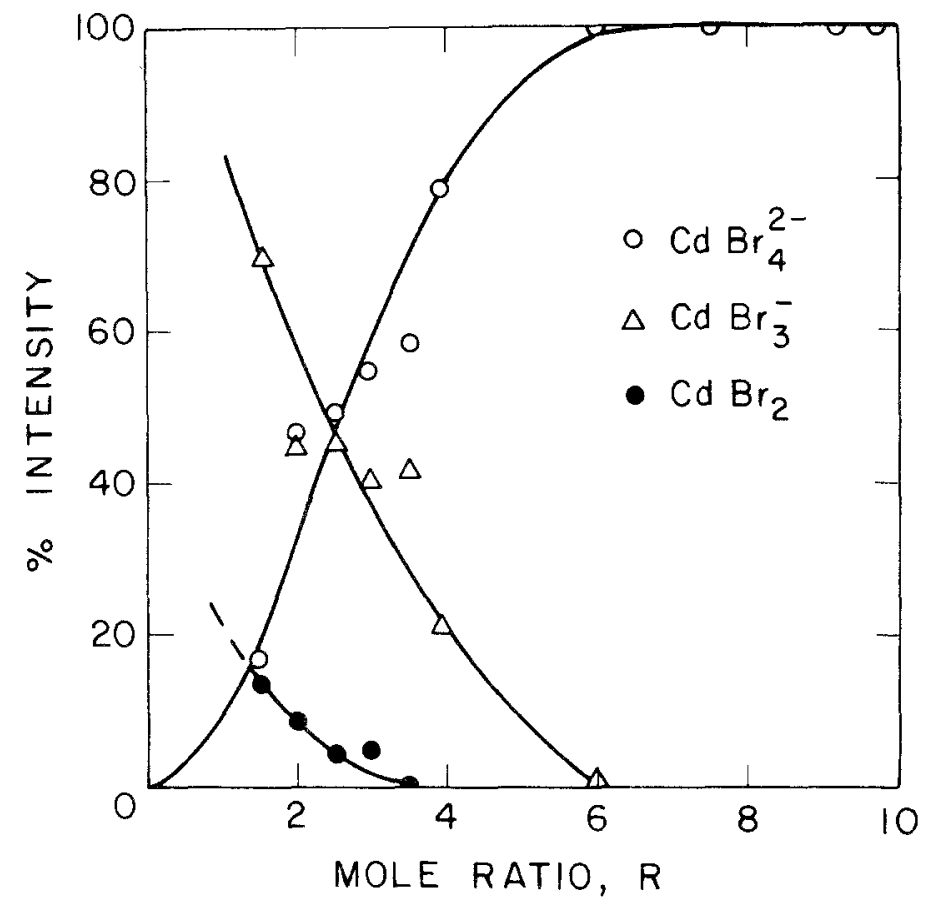

Fig. 7. Percentage of total integrated intensity due to each constituent $v s$. mole ratio at $200^{\circ} \mathrm{C}$.

Using the concentrations of the complexes determined above and the material balance equation of $\mathrm{Br}^{-}$

$$
\left[\mathrm{Br}^{-}\right]=\left[\mathrm{Br}^{-}\right]_{\text {total }}-3\left[\mathrm{CdBr}_{3}^{-}\right]-4\left[\mathrm{CdBr}_{4}^{2-}\right]
$$

an equlibrium constant $K_{4}^{200}=7 \pm 2$ was obtained.

Raman spectra of solutions with low $R$ values indicate that three species are present: $\mathrm{CdBr}_{2} ; \mathrm{CdBr}_{3}^{-} ;$and $\mathrm{CdBr}_{4}^{2-}$. However, electroneutrality demands that positively charged species such as $\mathrm{Cd}\left(\mathrm{H}_{2} \mathrm{O}\right)_{6}^{2+}$ and/or $\mathrm{CdBr}^{+}$must also exist. Macklin and Plane ${ }^{(10)}$ reported a band at $356 \mathrm{~cm}^{-1}$ due to $\mathrm{Cd}\left(\mathrm{H}_{2} \mathrm{O}\right)_{6}^{2+}$ which decreased rapidly in intensity with increasing $\mathrm{Br}^{-}$concentration. The same authors assigned a weak band at $200 \mathrm{~cm}^{-1}$ to $\mathrm{CdBr}^{+}$. The absence of both of these bands in the spectra reported here may be due to the high mole ratios used in this study. The absence of information concerning these two species made quantitative interpretation of equilibrium solution compositions impossible at low mole ratios. 


\section{SUMMARY}

Unlike aqueous solutions of $\mathrm{ZnBr}_{2}{ }^{(1)}$ the Raman spectra of aqueous solutions of $\mathrm{CdBr}_{2}$ show unresolved, featureless spectral contours which make interpretation difficult.

As for aqueous solutions of $\mathrm{ZnBr}_{2},{ }^{(1)}$ increased temperature causes the envelope of intensity from unresolved stretching modes of the cadmium bromide complexes to shift to higher wavenumbers, thus revealing that complexes with lower Br:Cd ratios are formed.

No evidence has been found to support the proposal of Ahrland and $\mathrm{Björk}^{(20)}$ that the change in coordination from octahedral [viz. $\left.\mathrm{Cd}\left(\mathrm{H}_{2} \mathrm{O}\right)_{6}^{2+}\right]$ to tetrahedral $\left(\mathrm{CdBr}_{4}^{2-}\right)$ takes place at the third step $\left[\mathrm{Cd}\left(\mathrm{H}_{2} \mathrm{O}\right) \mathrm{Br}_{3}^{-}\right]$. Our Raman spectra provide little information about structure because both the number of bands and their depolarization ratios cannot be positively inferred. The change in geometry with bromide ligand number was also reviewed by Ackerman et al.; ${ }^{(7)}$ although the NMR data are consistent with a transformation from octahedral geometry at $\mathrm{Cd}\left(\mathrm{H}_{2} \mathrm{O}\right) \mathrm{Br}_{3}{ }^{-}$the structural role of water is not clear.

The integrated molar intensity of the symmetric stretching mode of $\mathrm{CdBr}_{4}^{2-}$ is, within experimental error, the same as that of $\mathrm{ZnBr}_{4}^{2-}$ ( $v i z$. 8 intensity units relative to the intensity from $1.0 \mathrm{~m}$ TFMS anion) and thus the "softness" of the $\mathrm{Cd}^{2+}$ cation, relative to $\mathrm{Zn}^{2+}$, is not apparent in the change of polarizability with symmetric stretching. However, the stability constant (at $200^{\circ} \mathrm{C}$ ) is considerably larger for $\mathrm{CdBr}_{4}^{2-}$, than for $\mathrm{ZnBr}_{4}^{2-}$.

For both zinc and cadmium bromide solutions the ratios of the intensities of successive complexes, $I_{4}: I_{3}: I_{2}: I_{1}$, decrease faster than the ratio of the number of $\mathrm{Cd}-\mathrm{Br}$ bonds $4: 3: 2: 1$. This may suggest that, at least in part, the presence of water in the inner coordination sphere may endow greater ionic character to the cation-halide bonds.

\section{ACKNOWLEDGMENT}

This work was supported by grants from the Natural Sciences and Engineering Research Council of Canada. The authors express their thanks to Dr. Manfred Krell, Dr. David Guzonas, and Ms. Jaleh Semmer for their invaluable assistance during the course of this study.

\section{REFERENCES}

1. M. M. Yang, D. A. Crerar, and D. E. Irish, J. Solution Chem. 17, See September Issue (1988). 
2. R. G. Pearson, J. Am. Chem. So. 85, 3533 (1963); J. Chem. Ed. 45, 581, 643 (1968).

3. S. Ahrland, Structure and Bonding 15, 167 (1973).

4. H. Ohtaki and G. Johansson, Pure and Appl. Chem. 53, 1357 (1981).

5. S. Ahrland and N. O. Björk, Acta Chem. Scand. A. 30, 249 (1976).

6. Stability Constants of Metal-Ion Complexes, L. G. Sillén and A. E. Martell, ed., (Chemical Society, London, 1964); Suppl. No. 1 (1971).

7. J. J. H. Ackerman, T. V. Orr, V. J. Bartuska, and G. E. Maciel, J. Am. Chem. Soc. 101, 341 (1979).

8. W. Yellin and R. A. Plane, J. Am. Chem. Soc. 83, 2448 (1961) and references therein.

9. J. E. D. Davies and D. A. Long, J. Chem. Soc. A, 2054 (1968).

10. J. W. Macklin and R. A. Plane, Inorg. Chem. 9, 821 (1970).

11. D. E. Irish, T. Jarv, and C. I. Ratcliffe, Appl. Spectrosc. 36, 137 (1982).

12. J. T. Bulmer, D. E. Irish, F. W. Grossman, G. Herriot, M. Tseng, and A. J. Weerheim, Appl. Spectrosc. 29, 506 (1975).

13. E. R. Malinowski and D. G. Howery, Factor Analysis in Chemistry (Wiley, New York, 1980).

14. H. J. Shurvell and J. T. Bulmer, in Vibrational Spectra and Structure, J. R. Durig, ed., Vol. 6 (Elsevier Amsterdam, 1977) p. 91.

15. T. Jarv, J. T. Bulmer, and D. E. Irish, J. Phys. Chem. 81, 649 (1977).

16. E. R. Malinowski, Target 85 Programs (Lake Hiawatha, New Jersey, 1985).

17. E. R. Malinowski, Anal. Chim. Acta 134, 129 (1982).

18. J. Pitha and R. N. Jones, Can. J. Chem. 44, 3031 (1966); 45, 1271 (1964).

19. D. A. Long, Raman Spectroscopy, (McGraw-Hill, New York, 1977) p. 83.

20. S. Ahrland and N. O. Björk, Acta Chem. Scand. A30, 257 (1976). 